\title{
Regional climate variability in the western subtropical North Atlantic during the past two millennia
}

\author{
Casey Saenger, ${ }^{1,2}$ Rosemarie E. Came, ${ }^{3}$ Delia W. Oppo, ${ }^{4}$ Lloyd D. Keigwin, ${ }^{4}$ \\ and Anne L. Cohen ${ }^{4}$ \\ Received 5 August 2010; revised 28 January 2011; accepted 1 February 2011; published 21 April 2011.
}

[1] Western subtropical North Atlantic oceanic and atmospheric circulations connect tropical and subpolar climates. Variations in these circulations can generate regional climate anomalies that are not reflected in Northern Hemisphere averages. Assessing the significance of anthropogenic climate change at regional scales requires proxy records that allow recent trends to be interpreted in the context of long-term regional variability. We present reconstructions of Gulf Stream sea surface temperature (SST) and hydrographic variability during the past two millennia based on the magnesium/calcium ratio and oxygen isotopic composition of planktic foraminifera preserved in two western subtropical North Atlantic sediment cores. Reconstructed SST suggests low-frequency variability of $\sim 1^{\circ} \mathrm{C}$ during an interval that includes the Medieval Climate Anomaly (MCA) and the Little Ice Age (LIA). A warm interval near 1250 A.D. is distinct from regional and hemispheric temperature, possibly reflecting regional variations in ocean-atmosphere heat flux associated with changes in atmospheric circulation (e.g., the North Atlantic Oscillation) or the Atlantic Meridional Overturning Circulation. Seawater $\delta^{18} \mathrm{O}$, which is marked by a fresher MCA and a more saline LIA, covaries with meridional migrations of the Atlantic Intertropical Convergence Zone. The northward advection of tropical salinity anomalies by mean surface currents provides a plausible mechanism linking Carolina Slope and tropical Atlantic hydrology.

Citation: Saenger, C., R. E. Came, D. W. Oppo, L. D. Keigwin, and A. L. Cohen (2011), Regional climate variability in the western subtropical North Atlantic during the past two millennia, Paleoceanography, 26, PA2206, doi:10.1029/2010PA002038.

\section{Introduction}

[2] Reconstructions of Northern Hemisphere surface temperature during the late Holocene provide a longer-term context in which to interpret recent climate changes. A generally warm Medieval Climate Anomaly (MCA; 800-1250 A.D.) and a generally cool Little Ice Age (LIA; 1400-1850 A.D.) in these reconstructions indicate that anthropogenic influences on climate must be detected above a background of natural low-frequency variations. At hemispheric scales, $52-70 \%$ of decadal variance can be explained by changes in external radiative forcing, with detectable volcanic, greenhouse gas and sulfate aerosol signals [Hegerl et al., 2007]. However, at regional scales, internal oceanic and atmo\footnotetext{
USA.

${ }^{1}$ MIT/WHOI Joint Program in Oceanography, Woods Hole, Massachusetts,

${ }^{2}$ Now at Department of Geology and Geophysics, Yale University, New Haven, Connecticut, USA.

${ }^{3}$ Department of Earth Sciences, University of New Hampshire, Durham, New Hampshire, USA.

${ }^{4}$ Woods Hole Oceanographic Institution, Woods Hole, Massachusetts, USA.
}

Copyright 2011 by the American Geophysical Union. 0883-8305/11/2010PA002038 spheric dynamics can cause patterns of climate variability that differ from the hemispheric mean [Goosse et al., 2005].

[3] A recent proxy compilation provides valuable insight into the temporal and spatial patterns of regional climate variability during the Late Holocene [Mann et al., 2009]. However, this reconstruction relies heavily on terrestrial proxy records that span only a few hundred years [Mann et al., 2008, 2009], and thus lacks the spatial resolution to capture climatically important features of ocean circulation such as western boundary currents. Additional proxy reconstructions in these dynamic areas are needed to better constrain natural lowfrequency variability associated with the LIA and the MCA.

[4] The Gulf Stream carries large volumes of heat and salt across the North Atlantic to higher latitudes. Changes in Gulf Stream sea surface temperature (SST) and/or salinity are therefore of significance to circum-North Atlantic climate and the Atlantic Meridional Overturning Circulation (AMOC). SST and salinity variations in the Gulf Stream can be distinct from those outside the western boundary current in the open Atlantic [Halliwell, 1998; Mignot and Frankignoul, 2003], and are poorly documented over the past two millennia at decadalcentennial timescales. Here, we present a reconstruction of Gulf Stream SST and hydrologic variability in recent millennia that is based on the magnesium/calcium ratio $(\mathrm{Mg} / \mathrm{Ca})$ and oxygen isotopic $\left(\delta^{18} \mathrm{O}_{\mathrm{c}}\right)$ variations preserved in the carbonate 


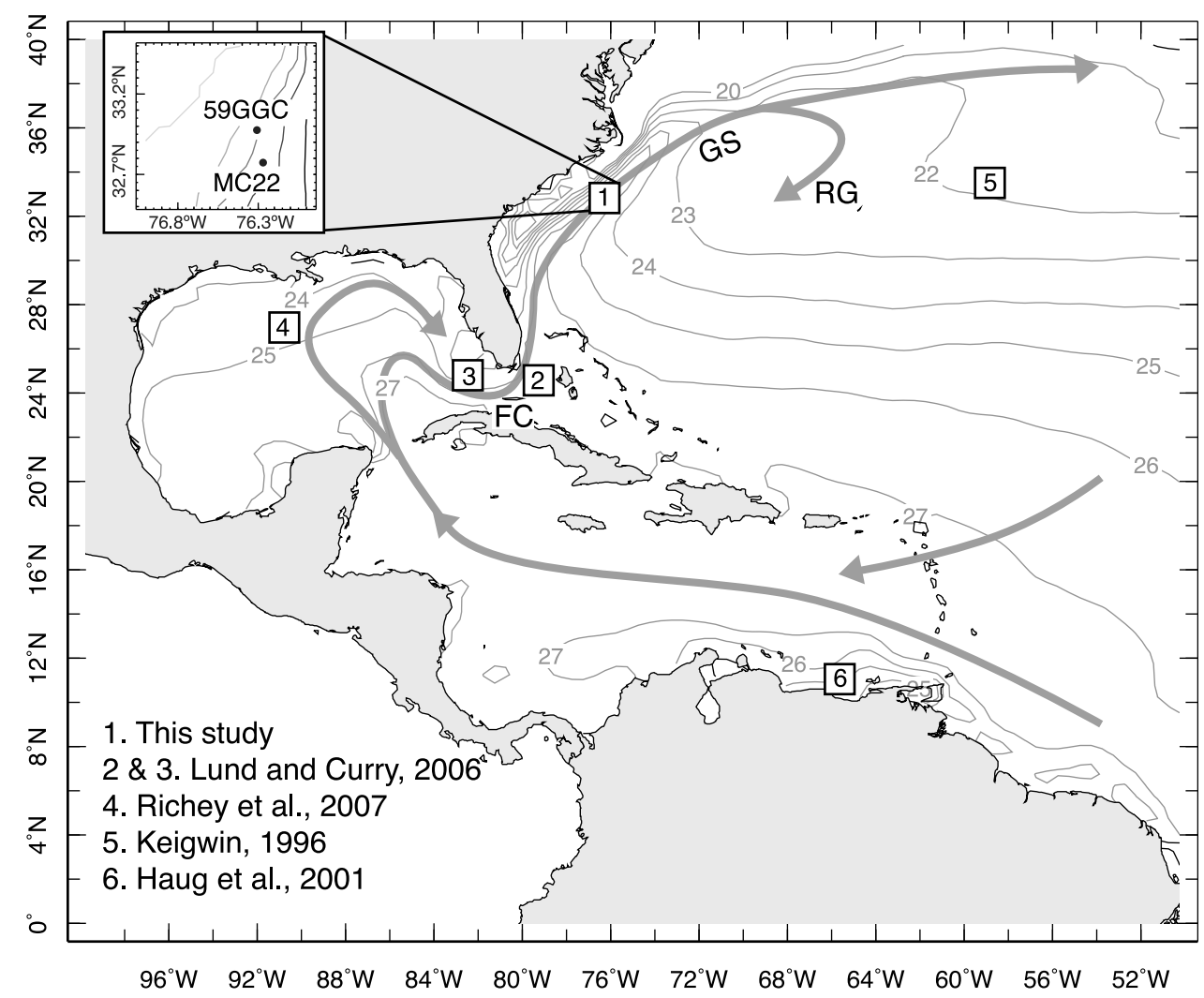

Figure 1. Map of low-latitude western North Atlantic mean annual SST 1958-2007 [Carton and Giese, 2008] and core sites discussed in the text, including (1) Carolina Slope (this study), (2) Great Bahama Bank [Lund and Curry, 2006], (3) Dry Tortugas [Lund and Curry, 2006], (4) Pigmy Basin [Richey et al., 2007], (5) Sargasso Sea [Keigwin, 1996], and (6) Cariaco Basin [Haug et al., 2001]. Arrows indicate the generalized regional ocean circulation including the Florida Current (FC), Gulf Stream (GS), and Gulf Stream recirculation gyres (RG). The relative positions of cores KNR-140-2-59GGC and CH07-98MC22 are shown (inset) with $500 \mathrm{~m}$ bathymetric contours.

shells of the foraminifera Globigerinoides ruber (G. ruber). We use these records to explore the pattern and possible causes of late Holocene climate variability in the Gulf Stream region of the western subtropical North Atlantic.

\section{Climatic Setting}

[5] Data were generated from the giant gravity core KNR140-2-59GGC $\left(32.977^{\circ} \mathrm{N}, 76.316^{\circ} \mathrm{W}, 1205 \mathrm{~m}\right)$ and the multicore CH07-98-MC22 $\left(32.784^{\circ} \mathrm{N}, 76.276^{\circ} \mathrm{W}, 1895 \mathrm{~m}\right)$, hereafter referred to as $59 \mathrm{GGC}$ and $\mathrm{MC} 22$, respectively (Figure 1). Separated by $22 \mathrm{~km}$ along the Carolina Slope, both core sites lie near the southern flank of the Gulf Stream and are exposed to nearly identical climate variations. Although turbulent flows are an important component of ocean circulation [e.g., Macdonald and Wunsch, 1996], simplified estimates of ocean volume transport suggest a flow of $\sim 31 \mathrm{~Sv}$ $\left(1 \mathrm{~Sv}=1 \times 10^{6} \mathrm{~m}^{3} \mathrm{~s}^{-1}\right)$ to the Carolina Slope that can be divided between AMOC $(\sim 13 \mathrm{~Sv})$ and wind-driven $(\sim 17 \mathrm{~Sv})$ components [Schmitz and Richardson, 1991; Schmitz and McCartney, 1993]. Shallow, complex wind-driven recirculation gyres enhance Carolina Slope transport, which reaches $\sim 100$ Sv near the Cape Hatteras separation [Schmitz and Richardson, 1991; Schmitz and McCartney, 1993; Wang and Koblinsky, 1996].
[6] Instrumental records of SST variability since 1854 [Smith et al., 2008] estimate mean annual Carolina Slope SST to be $24.8^{\circ} \mathrm{C}$ in the surface mixed layer where G. ruber is thought to calcify [Deuser and Ross, 1989; Anand et al., 2003]. A prominent feature of this record is the $\sim 1^{\circ} \mathrm{C}$ warm anomaly that occurred between 1930 and 1950 (Figure 2a). A similar pattern in detrended North Atlantic SST, referred to as the Atlantic Multidecadal Oscillation (AMO) (Figure 2b), has been attributed to small 70-80 year variations in the strength of the AMOC [Enfield et al., 2001; Knight et al., 2005]. This suggests ocean circulation likely plays a role in lowfrequency Carolina Slope SST variability. However, Carolina Slope SST does not exhibit the warming trend seen in the AMO since the 1970s suggesting that other factors also impact SST variability at our site.

[7] High-resolution reanalysis products [Carton and Giese, 2008] may better capture the sharp SST gradients that characterize the dynamic Gulf Stream region and they also provide an estimate of Carolina Slope salinity. Spanning the period from 1958 to 2007, these data estimate mean annual mixed layer Carolina Slope SST and salinity to be $25.9^{\circ} \mathrm{C}$ and 36.1 psu, respectively [Carton and Giese, 2008]. Decadal variability in these records shows cool/salty conditions in the mid-20th century that become progressively warmer/fresher in recent decades (Figures 2a, 2c, and 2d). Although this 
warming trend resembles the rise of the AMO from 1975 to the present, the reanalysis data does not clearly show warmer SSTs prior to 1970 when the AMO was less negative. Carolina Slope warming is also accompanied by a shift in atmospheric circulation toward the positive phase of the North Atlantic Oscillation (NAO) and decreased ocean to atmosphere latent heat flux (Figures 2e and 2f). This is consistent with a rapid and direct response of low-latitude Atlantic SST to the NAO's wind anomaly field [Visbeck et al., 1998]. Despite a similar
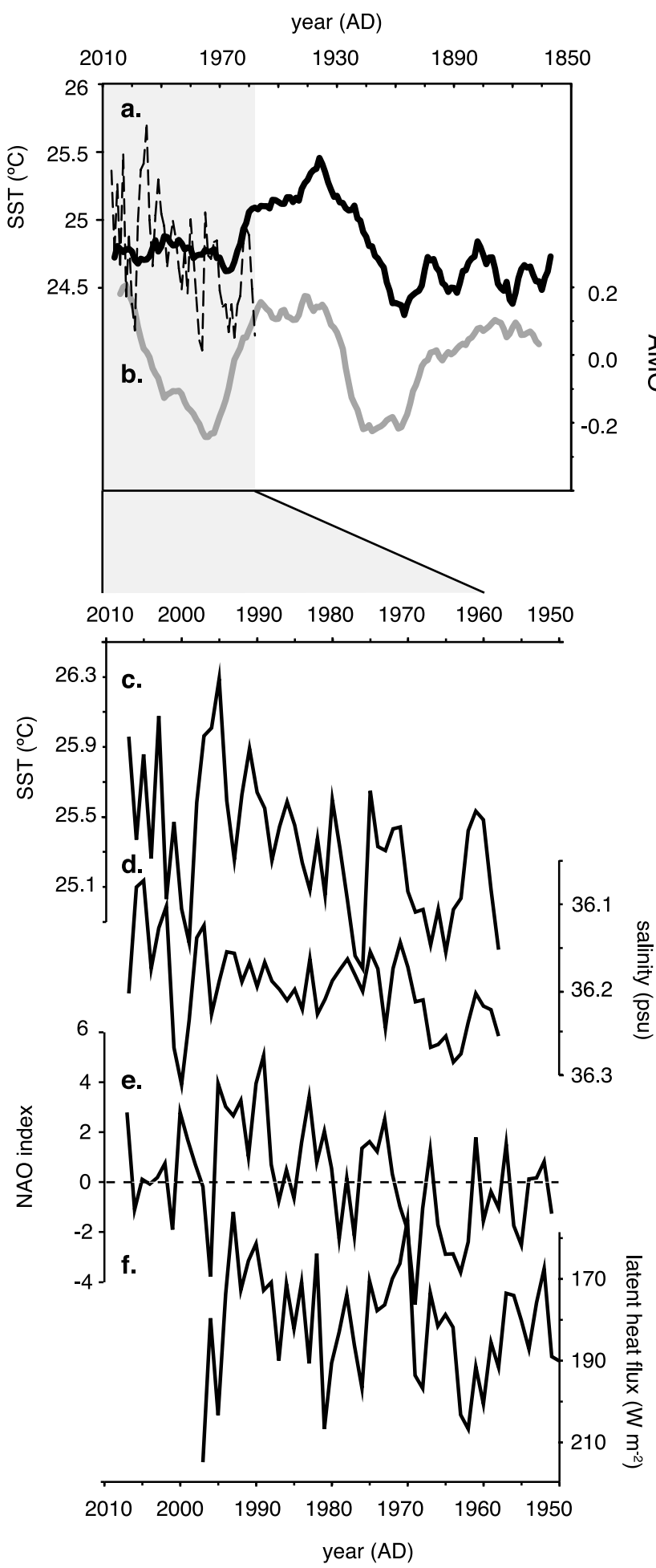

trend, salinity variability (Figure $2 \mathrm{~d}$ ) is more likely to reflect enhanced advection of relatively low-salinity tropical waters in the "upstream" Caribbean-Loop Current system [Mignot and Frankignoul, 2003].

\section{Methods}

\subsection{Core 59GGC Mg/Ca and $\delta^{18} \mathrm{O}_{\mathrm{c}}$}

[8] Initially, 59GGC was subsampled every $4 \mathrm{~cm}$ in the core's upper meter and every $8 \mathrm{~cm}$ from 100 to $441 \mathrm{~cm}$. G. ruber (white variety, sensu stricto) picked from the 150 $250 \mu \mathrm{m}$ size fraction were analyzed for $\delta^{18} \mathrm{O}_{\mathrm{c}}$ at the Woods Hole Oceanographic Institution (WHOI) using a VG 903 isotope ratio mass spectrometer. Replicate analyses were performed on $25 \%$ of these samples.

[9] Subsequently, $\sim 100 \mathrm{G}$. ruber from the 212-300 $\mu \mathrm{m}$ size fraction were picked at $1 \mathrm{~cm}$ resolution in the core's upper $70 \mathrm{~cm}$. Samples were weighed, gently crushed between glass slides, homogenized and split into aliquots with masses equivalent to $\sim 80$ and $\sim 15$ individuals for $\mathrm{Mg} / \mathrm{Ca}$ and $\delta^{18} \mathrm{O}_{\mathrm{c}}$ analyses, respectively. This generally allowed two $\mathrm{Mg} / \mathrm{Ca}$ and two $\delta^{18} \mathrm{O}_{\mathrm{c}}$ analyses at each depth interval. Oxygen isotope analyses on these samples used a Finnigan-MAT 253 with a Kiel III carbonate device at WHOI, which has a reproducibility of $\pm 0.08 \%$ o $(1 \sigma, \mathrm{n}=461)$.

[10] $\mathrm{Mg} / \mathrm{Ca}$ samples were cleaned using the full trace metal method including clay removal, metal oxide reduction and organic matter oxidation [Boyle and Keigwin, 1985; Rosenthal et al., 1995]. Core 59GGC Mg/Ca was analyzed at Rutgers University Inorganic Analytical Laboratory (RIAL) using a Thermo Element XR sector field inductively coupled plasma mass spectrometer (ICP-MS). The external precision of $\mathrm{Mg} / \mathrm{Ca}$ analyses was $\sim 1.1 \%$ ( $1 \sigma \mathrm{RSD})$ based on repeated measurements of three consistency standards with $\mathrm{Mg} / \mathrm{Ca}$ ratios between 1.2 and $7.5 \mathrm{mmol} / \mathrm{mol}$. This is equivalent to $\pm 0.12^{\circ} \mathrm{C}$ at typical $G$. ruber ratios.

\subsection{Core $\mathrm{MC22} \mathrm{Mg} / \mathrm{Ca}$ and $\delta^{18} \mathrm{O}_{\mathrm{c}}$}

[11] Approximately 50 G. ruber were picked every centimeter from the 212-250 $\mu \mathrm{m}$ size fraction of MC22. Prior to crushing, samples were split into aliquots of 40 individuals for $\mathrm{Mg} / \mathrm{Ca}$ and 10 individuals for $\delta^{18} \mathrm{O}_{\mathrm{c}}$ analyses. This generally allowed two $\delta^{18} \mathrm{O}_{\mathrm{c}}$ analyses at each depth interval, but only one $\mathrm{Mg} / \mathrm{Ca}$ analysis. After gently crushing and cleaning as above, G. ruber $\mathrm{Mg} / \mathrm{Ca}$ samples were analyzed at WHOI using a Thermo-Finnigan Element 2 sector field ICP-MS.

Figure 2. (a) Seven-point moving average of Carolina Slope mixed layer $(0-50 \mathrm{~m})$ temperature in the $2^{\circ} \times 2^{\circ}$ grid box closest to our core sites from 1854 to 2009 [Smith et al., 2008] (thick black line) and annual average Carolina Slope mixed layer temperature $(0-50 \mathrm{~m})$ from the SODA reanalysis product in the $0.5^{\circ} \times 0.5^{\circ}$ grid box closest to our core sites from 1958 to 2007 [Carton and Giese, 2008] (dashed line). SODA SST was scaled to have the same 1970-1990 mean as Smith et al. [2008]. (b) The Atlantic Multidecadal Oscillation (AMO), calculated as the detrended, area-weighted average of North Atlantic SST from $0^{\circ} \mathrm{N}$ to $70^{\circ} \mathrm{N}$ [Enfield et al., 2001]. (c) SODA data as in Figure 2a without scaling. (d) As in Figure 2c for SODA salinity reanalysis. (e) December to March station-based NAO index [Hurrell et al., 2003]. (f) Annual average ocean-atmosphere latent heat flux [Cayan, 1992]. 
Table 1. Radiocarbon Ages for Cores CH0798-MC22 and KNR140-2-59GGC

\begin{tabular}{|c|c|c|c|c|c|c|c|}
\hline Core & ID & Depth $(\mathrm{cm})$ & ${ }^{14} \mathrm{C}$ Age (years BP) & 1 Standard Deviation & $\begin{array}{l}\text { Calibrated Age } \\
\text { (years B.P.) }\end{array}$ & 1 Standard Deviation & Species \\
\hline CH0798-MC-22 & OS-50129 & $0-1$ & 260 & 35 & $\operatorname{modern}^{\mathrm{a}}$ & - & G. sacculifer \\
\hline CH0798-MC-22 & OS-59672 & $30-31$ & 1350 & 30 & 1023 & 38 & G. sacculifer \\
\hline CH0798-MC-22 & OS-59833 & $55-56$ & 2160 & 40 & 1878 & 40 & G. sacculifer \\
\hline KNR140-2-59GGC & 7908 & $0-2$ & 375 & 85 & $\operatorname{modern}^{\mathrm{a}}$ & - & mixed planktic \\
\hline KNR140-2-59GGC & OS-65593 & $10-11$ & 825 & 30 & 591 & 36 & G. sacculifer \\
\hline KNR140-2-59GGC & OS-65595 & $20-21$ & 1100 & 30 & 778 & 44 & G. sacculifer \\
\hline KNR140-2-59GGC & OS-65596 & $35-36$ & 1350 & 30 & 1023 & 38 & G. sacculifer \\
\hline KNR140-2-59GGC & OS-65598 & $69-70$ & 1910 & 30 & 1578 & 39 & G. sacculifer \\
\hline KNR140-2-59GGC & 7909 & $296-298$ & 4920 & 60 & 5428 & 85 & mixed planktic \\
\hline
\end{tabular}

${ }^{\mathrm{a}} \mathrm{MC} 22$ and 59GGC core top fraction modern values are $97 \%$ and $95 \%$, respectively.

Long-term external precision was $\sim 1.2 \%$ ( $1 \sigma \mathrm{RSD})$ based on repeated measurements of three consistency standards with $\mathrm{Mg} / \mathrm{Ca}$ ratios of $1.7,3.3$ and $5.0 \mathrm{mmol} / \mathrm{mol}$. Stable isotope analyses were performed at WHOI on uncrushed individuals following the method above.

\section{3. $\mathrm{SST}$ and $\delta^{18} \mathrm{O}_{\text {sw }}$ Estimates}

[12] $\mathrm{Mg} / \mathrm{Ca}$-based SST estimates are often subtracted from $\delta^{18} \mathrm{O}_{\mathrm{c}}$ to yield estimates of seawater $\delta^{18} \mathrm{O}\left(\delta^{18} \mathrm{O}_{\mathrm{sw}}\right)$ [e.g., Lund and Curry, 2006; Richey et al., 2007]. Following this approach, we estimated SST using a $\mathrm{Mg} / \mathrm{Ca}-\mathrm{SST}$ calibration based on Sargasso Sea G. ruber [Anand et al., 2003]:

$$
\mathrm{Mg} / \mathrm{Ca}(\mathrm{mmol} / \mathrm{mol})=0.34 \exp \left(0.104 * \operatorname{SST}\left({ }^{\circ} \mathrm{C}\right)\right) .
$$

SST estimates were then combined with a $G$. ruber-specific $\delta^{18} \mathrm{O}_{\mathrm{c}}$-SST relationship [Mulitza et al., 2003] to estimate seawater $\delta^{18} \mathrm{O}\left(\delta^{18} \mathrm{O}_{\mathrm{sw}}\right)$ :

$$
\operatorname{SST}\left({ }^{\circ} \mathrm{C}\right)=-4.44\left(\delta^{18} \mathrm{O}_{\mathrm{c}}(\mathrm{PDB})-\delta^{18} \mathrm{O}_{\mathrm{sw}}(\mathrm{SMOW})\right)+14.20 .
$$

The modern relationship between salinity and $\delta^{18} \mathrm{O}_{\mathrm{sw}}$ is roughly linear in a given region, but varies spatially and temporally [Schmidt, 1999]. G. A. Schmidt et al. (Global Seawater Oxygen-18 Database, 1999, available at http://data.giss.nasa. gov/o18data/) estimate a modern low-latitude North Atlantic $\left(14.3^{\circ}-33.3^{\circ} \mathrm{N}, 50.8^{\circ}-92.4^{\circ} \mathrm{W}\right)$ relationship of

$$
\delta^{18} \mathrm{O}_{\mathrm{sw}}(\mathrm{SMOW})=0.32 * \operatorname{salinity}(\mathrm{psu})-10.42 .
$$

\subsection{Age Model}

[13] The chronology for each core is based on several planktic foraminiferal radiocarbon ages (Table 1). Assuming a model-based Carolina Slope reservoir correction of 225 years [Butzin et al. 2005] (http://radiocarbon.ldeo.columbia.edu/ research/resage/res_ff.cgi?add=1\&id=10085\&lon $=283.5 \&$ lat=33), we calculated calendar ages using the calibration curve of Fairbanks et al. [2005] (http://radiocarbon.ldeo.columbia. edu/research/radcarbcal.htm).

\section{Results}

\subsection{Sedimentation Rates}

[14] Three radiocarbon dates in MC22 support a constant sedimentation rate of $29 \mathrm{~cm} \mathrm{kyr}^{-1}$, and five ages in 59GGC suggest a constant sedimentation rate of $59 \mathrm{~cm} \mathrm{kyr}^{-1}$ prior to $\sim 1500$ A.D. (Table 1 and Figure 3). Sediments in the upper
$2 \mathrm{~cm}$ of 59GGC have a modern age but fall off the constant $59 \mathrm{~cm} \mathrm{kyr}^{-1}$ sedimentation line. A fraction modern radiocarbon of $95 \%$ in this core top sample suggests some reworking of upper sediments, but the cause of this apparent change in sedimentation rate remains unclear. Although other age models are possible, we make the reasonable assumption that linear sedimentation of $16 \mathrm{~cm} \mathrm{kyr}^{-1}$ occurred in the upper $10 \mathrm{~cm}$ of $59 \mathrm{GGC}$ and we interpret this interval cautiously.

\section{2. $\mathrm{Mg} / \mathrm{Ca}$ and $\delta^{18} \mathrm{O}_{\mathrm{c}}$}

[15] The initial 59GGC $\delta^{18} \mathrm{O}_{\mathrm{c}}$ record, with a 4-8 cm sampling resolution, spans the last $\sim 5000$ years and suggests that the site captures suborbital-scale oceanographic variability since the middle Holocene (Figure 4). These data provided a framework to develop higher-resolution records of late Holocene variability from the core's upper $70 \mathrm{~cm}$. Comparing initial $4 \mathrm{~cm}$ resolution sampling with subsequent $1 \mathrm{~cm}$ scale data shows similar $\delta^{18} \mathrm{O}_{\mathrm{c}}$ variability between the two data sets. A systematic offset of $\sim 0.25 \%$ (Figure 4 inset), likely reflects different analytical methods (e.g., size fraction, mass spectrometer, etc.). Regardless, the synchronous highfrequency variations support the use of this core for investigating climate variability in recent millennia.

[16] Focusing on this recent interval, 59GGC and MC22 $\delta^{18} \mathrm{O}_{\mathrm{c}}$ average $-1.58 \pm 0.22 \%$ and $-1.62 \pm 0.22 \%$ o $(1 \sigma)$, respectively (Figure 5). The 59GGC $\delta^{18} \mathrm{O}_{\mathrm{c}}$ decreases by $\sim 0.5 \%$ between 70 and $50 \mathrm{~cm}$ to a relatively constant value near $-1.6 \%$ from 20 to $50 \mathrm{~cm}$ before increasing again to $-1.4 \%$ near the core top. This pattern of variability is similar to that seen in the Sargasso Sea [Keigwin, 1996], but $\delta^{18} \mathrm{O}_{\mathrm{c}}$ is systematically lower, consistent with lower Carolina Slope salinity. MC22 also shows a similar, but more subtle, trend that exhibits a slight $\sim 0.2 \%$ decrease above $47 \mathrm{~cm}$ followed by constant values of $\sim 1.7 \%$ until a slight increase to $\sim 1.6 \%$ near the core top.

[17] Mean $\mathrm{Mg} / \mathrm{Ca}$ was identical within uncertainty in the two cores with values of $4.42 \pm 0.18 \mathrm{mmol} / \mathrm{mol}$ and $4.44 \pm$ $0.17 \mathrm{mmol} / \mathrm{mol}(1 \sigma)$ in $59 \mathrm{GGC}$ and $\mathrm{MC} 22$, respectively (Figure 5). Based on our age model, low values of $\sim 4.3 \mathrm{mmol} / \mathrm{mol}$ near $70 \mathrm{~cm}$ in $59 \mathrm{GGC}$ correspond to similar values near $45 \mathrm{~cm}$ in MC22. Following this nadir, both records increase to $\sim 4.4-4.6 \mathrm{mmol} / \mathrm{mol}$ and generally reach their highest values near the core top.

\subsection{SST and $\delta^{18} \mathrm{O}_{\text {sw }}$}

[18] To reduce uncertainties associated with age model errors and sedimentary smoothing when comparing SST and $\delta^{18} \mathrm{O}_{\mathrm{sw}}$ between the two cores we averaged data into a series 


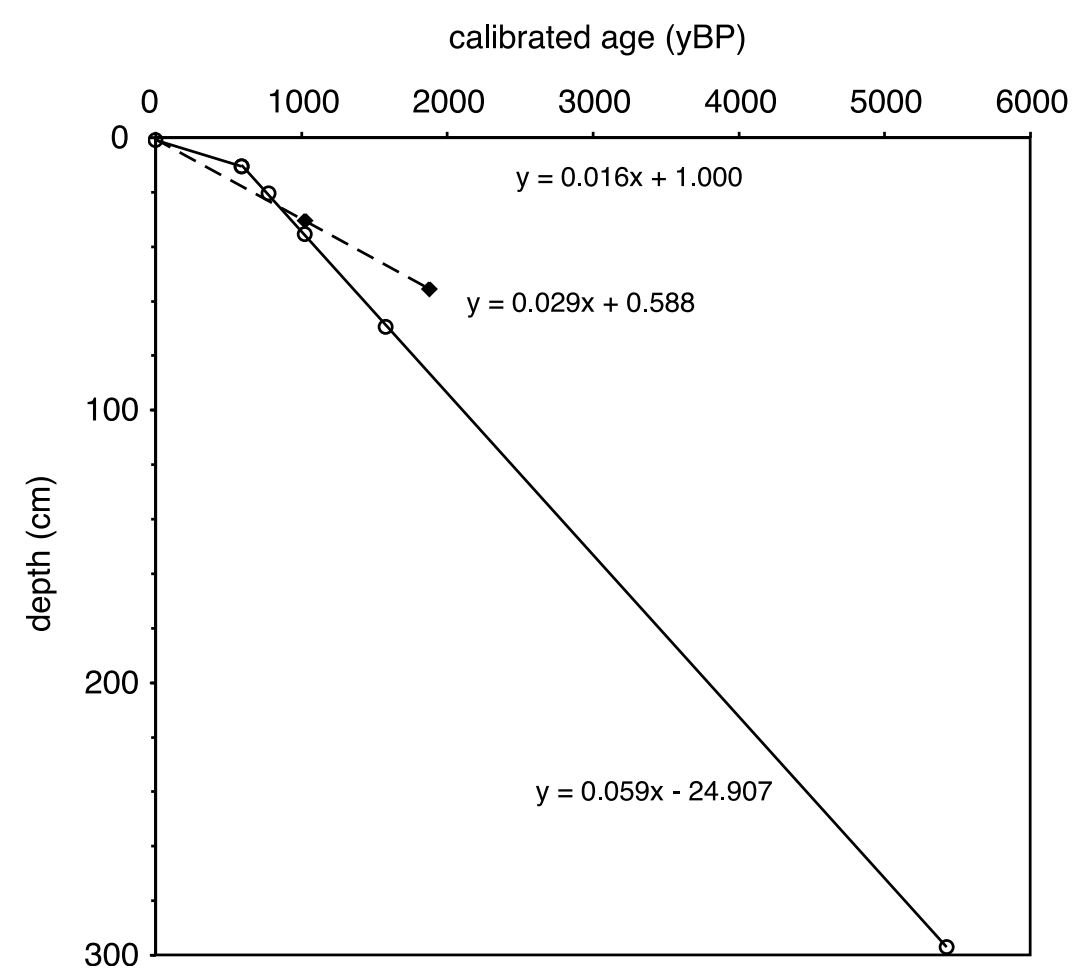

Figure 3. Radiocarbon age versus depth plot for 59GGC (open circles) and MC22 (solid diamonds). Sedimentation rates are based on linear regression through all dates, except for the 59GGC core top.

of overlapping bins. Below $10 \mathrm{~cm}, 59 \mathrm{GGC}$ data were averaged into 100 year bins, which overlapped neighboring bins by 50 years. Because of lower sedimentation rates and fewer replicate measurements in MC22 and above $10 \mathrm{~cm}$ in
59GGC, these data were averaged in 200 year bins shifted in 100 year increments. Assuming an optimistic $\mathrm{Mg} / \mathrm{Ca}-\mathrm{SST}$ calibration error of $\pm 0.5^{\circ} \mathrm{C}$, our analytical precisions and the method of Rohling [2007] estimate absolute SST and $\delta^{18} \mathrm{O}_{\mathrm{sw}}$

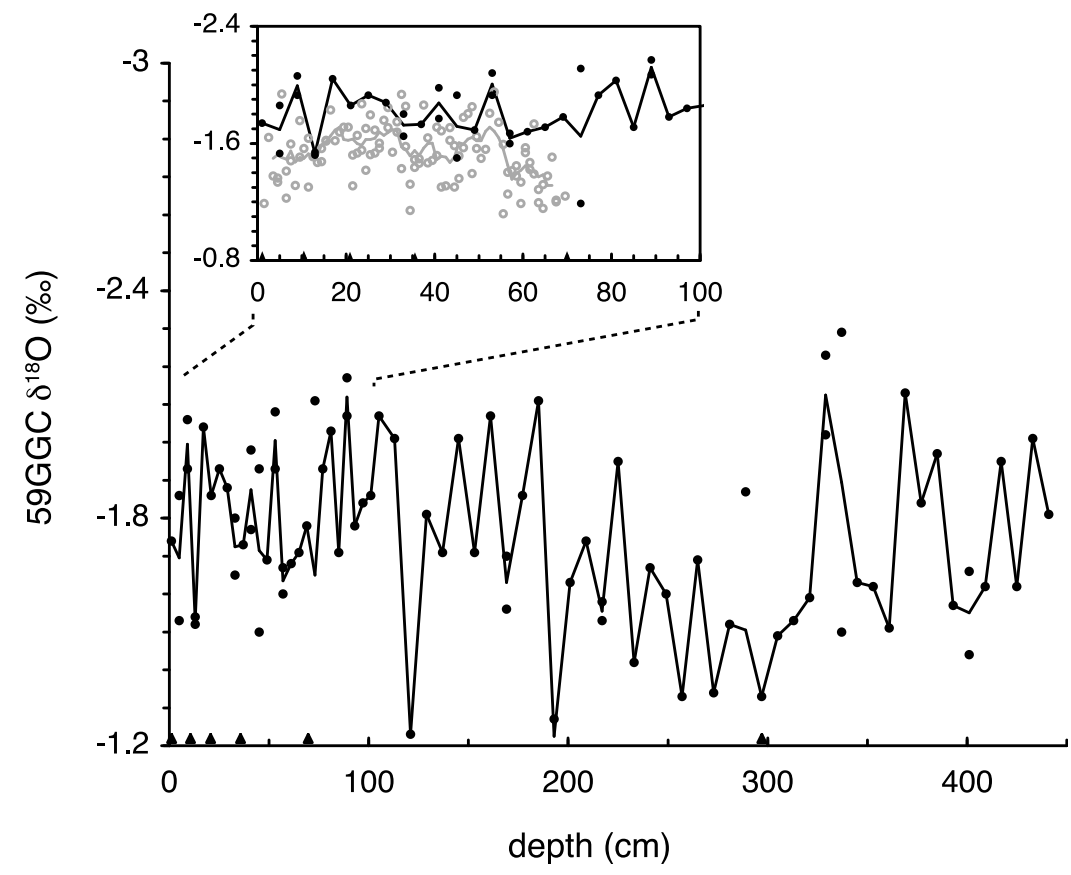

Figure 4. Initial 4-8 cm resolution 59GGC $\delta^{18} \mathrm{O}_{\mathrm{c}}$. Individual measurements (filled circles) have been averaged (black line) where replicate analyses were conducted. (inset) This data is compared with individual measurements (gray open circles) and a five-point moving average (gray line) of $1 \mathrm{~cm}$ resolution $59 \mathrm{GGC} \delta^{18} \mathrm{O}_{\mathrm{c}}$ in the upper $70 \mathrm{~cm}$. Triangles denote the depths of radiocarbon dates. 

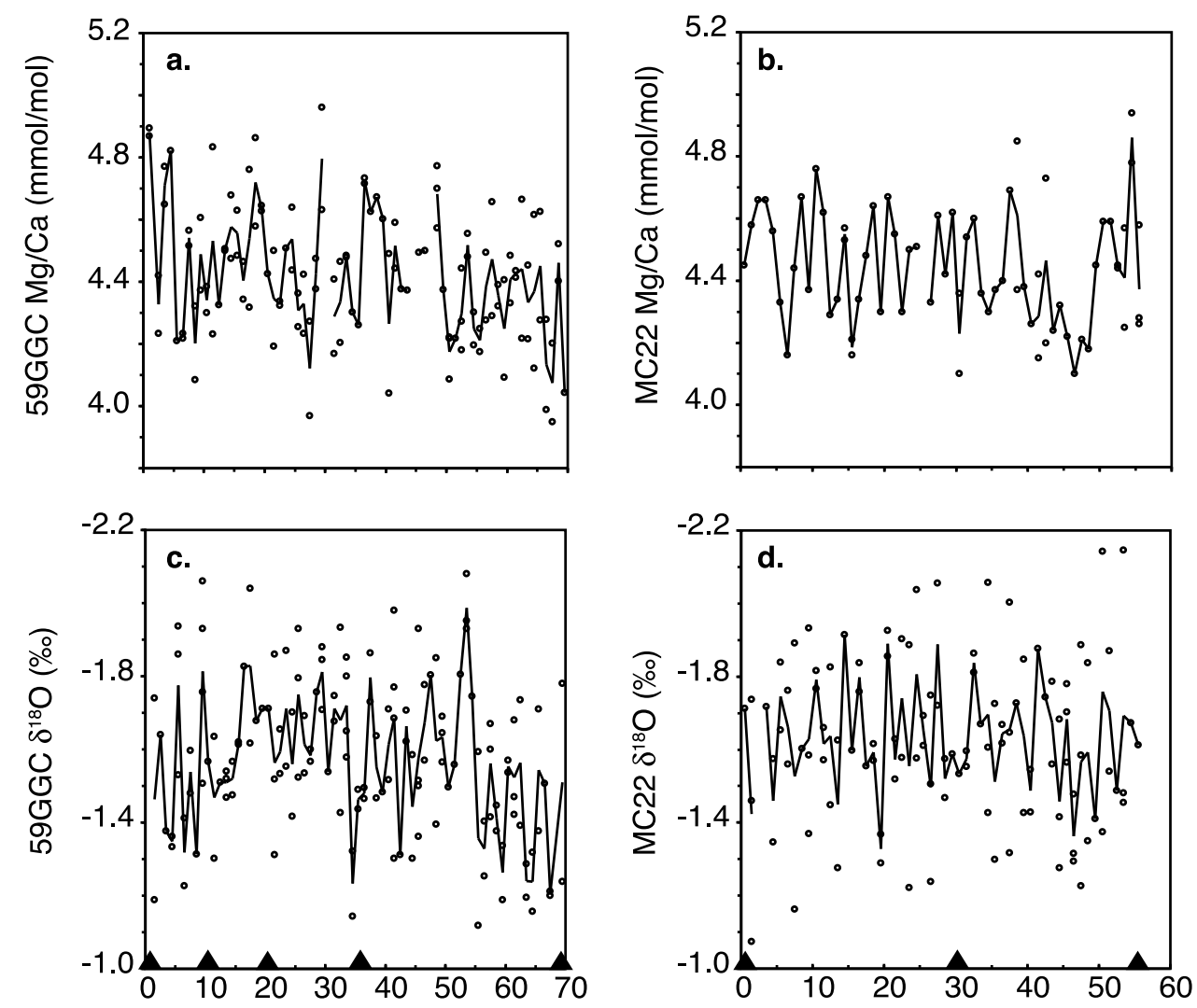

depth $(\mathrm{cm})$

Figure 5. (a) Individual measurements of $59 \mathrm{GGC} \mathrm{Mg} / \mathrm{Ca}$ (circles) and the mean value at each depth (line). (b) As in Figure 5a for MC22. (c) Individual measurements of 59GGC $\delta^{18} \mathrm{O}_{\mathrm{c}}$ (circles) and the mean value at each depth (line). (d) As in Figure 5c for MC22. Triangles denote the depths of radiocarbon dates.

uncertainties $(1 \sigma)$ of about $\pm 0.67^{\circ} \mathrm{C}$ and $\pm 0.22 \%$, respectively. A more conservative $\mathrm{Mg} / \mathrm{Ca}-\mathrm{SST}$ calibration error of $\pm 1^{\circ} \mathrm{C}$ estimates SST and $\delta^{18} \mathrm{O}_{\text {sw }}$ uncertainties $(1 \sigma)$ of $1.17^{\circ} \mathrm{C}$ and $0.40 \%$, respectively. However, following Lund and Curry [2006], if all samples have similar analytical and calibration errors, SST and $\delta^{18} \mathrm{O}_{\text {sw }}$ errors may be estimated by calculating the standard error in each bin. This approach is reasonable for assessing relative changes in SST and $\delta^{18} \mathrm{O}_{\mathrm{sw}}$ during the past two millennia.

[19] $\mathrm{Mg} / \mathrm{Ca}$-based SST in the upper two centimeters of MC22 estimates an early 20th century value of $25.4 \pm 0.2^{\circ} \mathrm{C}$ that is similar to the climatological mean. Our MC22 core top $\delta^{18} \mathrm{O}_{\text {sw }}$ value of $1.21 \pm 0.25 \%$ is slightly higher than a model-based estimate of 0.88\% [LeGrande and Schmidt, 2006], but according to equation (3), corresponds to a core top MC22 salinity of about $36.4 \pm 0.8 \mathrm{psu}$. This agrees well with a climatological value of $36.1 \mathrm{psu}$.

[20] Downcore SST and $\delta^{18} \mathrm{O}_{\mathrm{sw}}$ data for both cores show only subtle variability over the past 1500 years (Figure 6). Relatively cool SSTs in 59GGC near 500 A.D. warm to $\sim 25.3^{\circ} \mathrm{C}$ after 700 A.D. A cooling of $\sim 0.4^{\circ} \mathrm{C}$ after $\sim 1250$ A.D. is followed by a general warming trend in recent centuries. With the exception of an excursion near 650 A.D., 59GGC $\delta^{18} \mathrm{O}_{\mathrm{sw}}$ is generally higher from 400 to 1000 A.D. Lower values from 1000 to 1250 A.D. increase toward the core top, but this trend is not significant after $\sim 1500$ A.D.

[21] In general, MC22 SST and $\delta^{18} \mathrm{O}_{\mathrm{sw}}$ estimates are similar to those in 59GGC. Cool SSTs from 300 to 500 A.D. warm by $\sim 0.5^{\circ} \mathrm{C}$ to a mean of $\sim 25.3^{\circ} \mathrm{C}$ from 500 to 1250 A.D. A small cool interval may occur near 1500 A.D. and is followed by the hint of a warming trend in recent centuries. However, because SST and $\delta^{18} \mathrm{O}_{\mathrm{sw}}$ variability in the lower sedimentation rate MC22 core is damped and within the error of our method, we cannot consider it significant without further replication. We therefore focus our discussion on 59GGC variability.

\section{Discussion}

\subsection{SST Variability}

[22] Although the small anomalies reconstructed in both cores suggest Carolina Slope SST has not changed markedly in the past 1500 years, the subtle changes show some significant differences from hemispheric temperature. During the MCA-LIA transition, where our age model is robust, hemispheric temperatures begin cooling toward the LIA after $\sim 1000$ A.D. (Figure 7d). LIA cooling also begins at this time in the Gulf of Mexico [Richey et al., 2007] and near the Great 

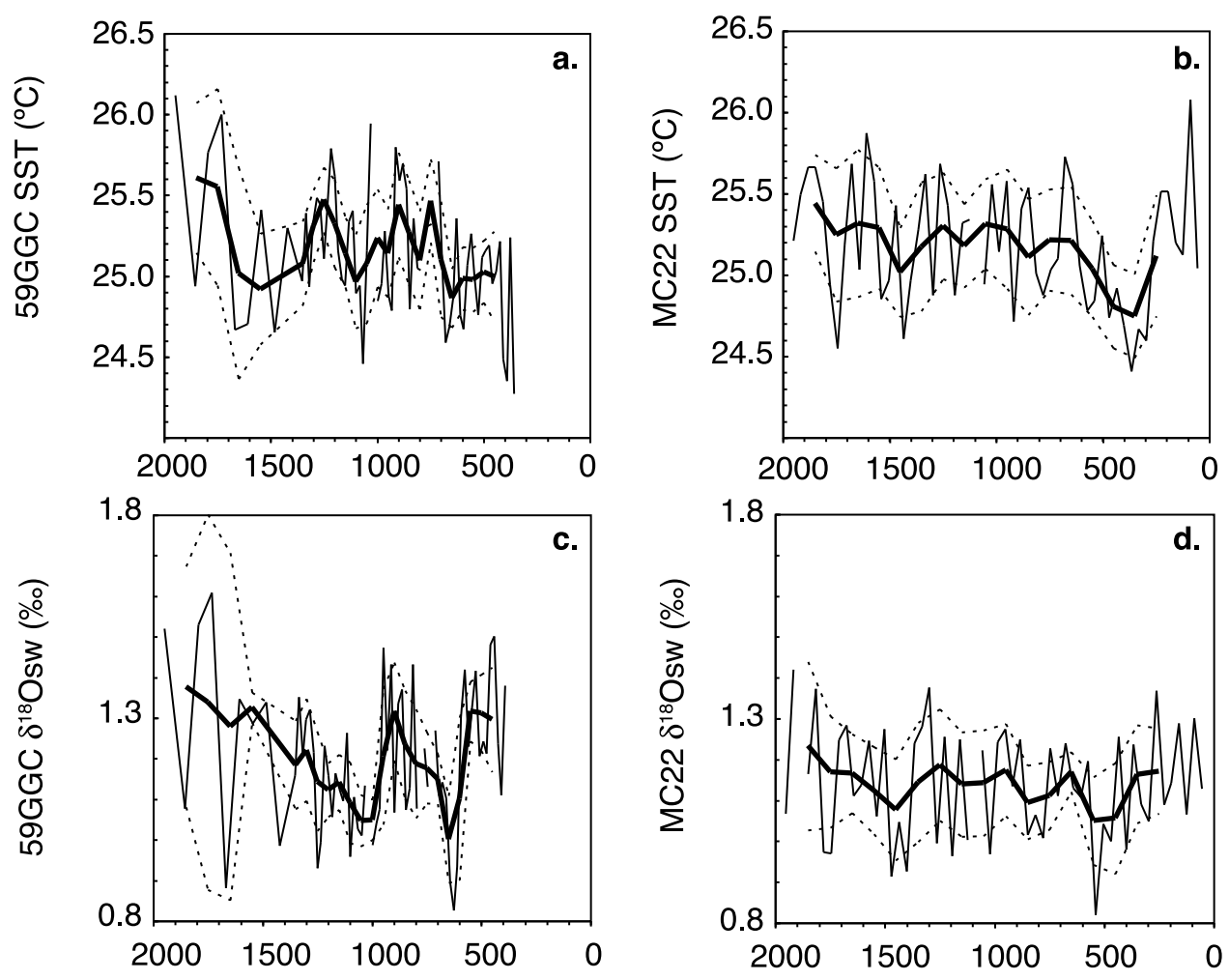

year $(A D)$

Figure 6. (a) Average $59 \mathrm{GGC} \mathrm{Mg} / \mathrm{Ca}$-based SST at each depth after applying our age model (thin line) and in overlapping bins (thick line) with associated one sigma standard error (dashed line). (b) As in Figure 6a for MC22. (c) Average 59GGC $\delta^{18} \mathrm{O}_{\mathrm{sw}}$ at each depth after applying our age model (thin line) and in overlapping bins (thick line) with associated one sigma standard error (dashed line). (d) As in Figure 6c for MC22.

Bahama Bank [Lund and Curry, 2006] (Figure 7e), suggesting similar responses to common forcings.

[23] In contrast, Carolina Slope SSTs exhibit a pronounced warm period near 1250 A.D., well after other regional records have started to cool (Figure 7a). It is unclear if this warm interval reflects the continuation of higher MCA SSTs or a warm reversal following an initial cooling near 1000 A.D. In any case, our 59GGC reconstruction demonstrates that the Carolina Slope experienced SST variability that is not evident in hemispheric [Mann et al. 2008] and other regional [Lund and Curry, 2006; Richey et al., 2007] proxy records.

[24] Carolina Slope warmth during and after the MCA may reflect the regional influence of centennial-scale NAOlike circulation, possibly in response to solar forcing. Proxy reconstructions of solar irradiance describe variability during the past two millennia as an 11 year cycle superimposed upon a slowly varying baseline [Lean et al., 1995]. Although considerable uncertainty exists in how to scale proxy data to radiative forcing, most reconstructions show patterns of centennial-scale baseline variability [Bard et al., 2000; Bard and Frank, 2006; Usoskin et al., 2008] that are similar to Carolina Slope SST (Figure 7b). Periods of weak solar forcing generally correspond to cooler SSTs, while periods of enhanced solar forcing, including a period near 1250 A.D., correspond to warmer SSTs.
[25] Attempts to isolate the influence of irradiance on climate indicate that the solar variability shown in Figure $7 \mathrm{~b}$ would cause Carolina Slope SST anomalies of only a few tenths of a degree [Lean and Rind, 2008]. However, irradiance-induced changes to atmospheric circulation may significantly amplify the climatic impact of solar anomalies. Global climate models suggest irradiance anomalies are capable of causing atmospheric circulation patterns resembling modern NAO phases [Shindell et al., 2001]. Positive irradiance anomalies warm low-latitude SSTs creating stratospheric temperature gradients that ultimately give rise to enhanced tropospheric westerlies and a circulation pattern similar to the positive phase of the NAO [Shindell et al., 2001]. A circulation resembling the negative phase of the NAO occurs during periods of reduced irradiance. Although the modern NAO is an interannual phenomenon that is most pronounced in winter, its circulation pattern has been used to describe centennial to millennia-scale climate variability during the Holocene [e.g., Sachs, 2007]. To avoid confusion with the modern NAO, we refer to low-frequency circulation patterns resembling the NAO as NAO-like.

[26] We suggest higher solar irradiance from $\sim 700$ 1250 A.D. may have shifted atmospheric circulation toward a more positive NAO-like state, while negative NAO-like conditions prevailed after 1250 A.D. This possibility is supported by high-resolution reconstructions that indicate a 
large-scale reorganization of atmospheric circulation near 1250 A.D. resembled the negative NAO (Figure 7c) [Laird et al., 1996; Trouet et al., 2009]. If modern, decadal-scale NAO relationships are applicable to our low-frequency record, a positive NAO-like circulation prior to 1250 A.D. may have forced positive SST anomalies near the Carolina Slope [Visbeck et al., 1998]. These anomalies may have been caused by a northward shift of the zero wind stress curl line over the Atlantic, which reduced the ocean to atmo-

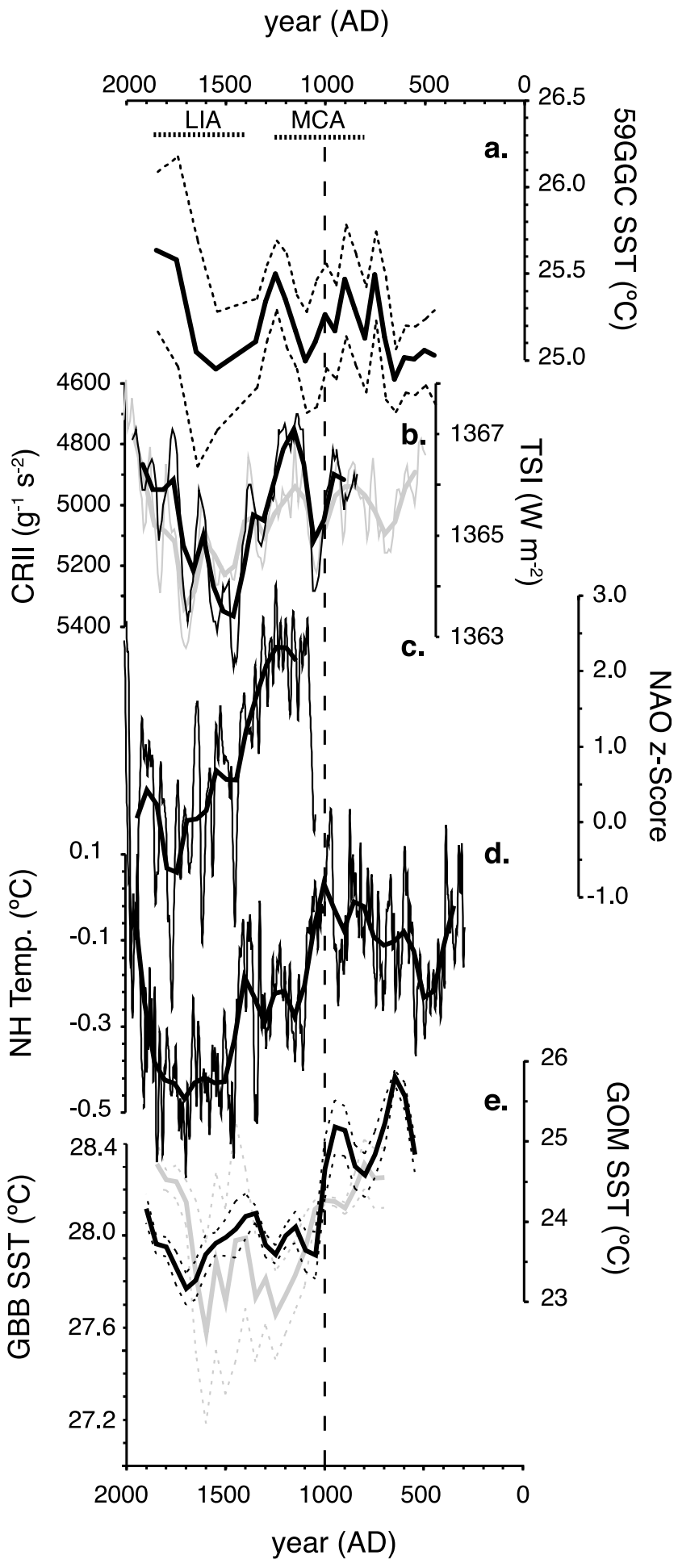

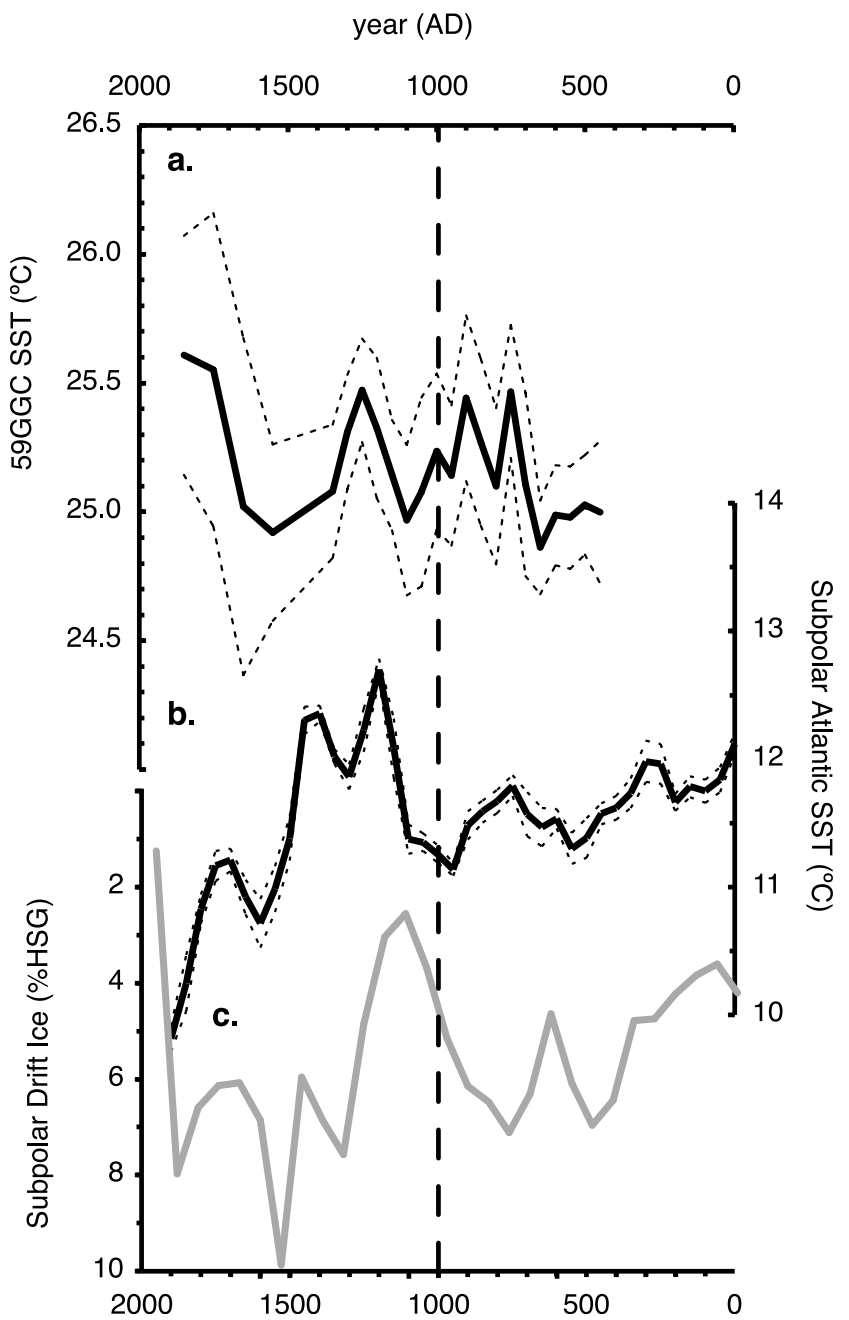

Figure 8. (a) One hundred year binned 59GGC SST and one sigma standard error. (b) One hundred year binned planktic foraminifera-based subpolar North Atlantic SST and one sigma standard error [Andersson et al., 2003]. (c) Subpolar drift ice based on a multicore stack of percent hematite stained grains [Bond et al., 2001].

sphere heat flux along the Carolina Slope and warmed SSTs [Battisti et al., 1995; Marshall et al., 2001]. If this effect was sufficiently large near the Carolina Slope, it may have temporarily offset the cooling observed throughout the

Figure 7. (a) One hundred year binned 59GGC SST and one sigma standard error. (b) Cosmic ray induced ionization (CRII, gray) [Usoskin et al., 2008] and total solar irradiance (black) [Bard et al., 2000]. (c) NAO z scores [Trouet et al., 2009]. (d) Northern Hemisphere (NH) surface temperature [Mann et al., 2008]. (e) One hundred year binned Gulf of Mexico (GOM) SST and one sigma standard error (black) [Richey et al., 2007] and 100 year binned Great Bahama Bank (GBB) SST and one sigma standard error (gray) [Lund and Curry, 2006]. Thick lines in Figures $7 \mathrm{~b}-7 \mathrm{~d}$ are 100 year bins. The approximate timing of the MCA and LIA are marked, as is the switch to a cooling trend near 1000 A.D. in NH temperature. 


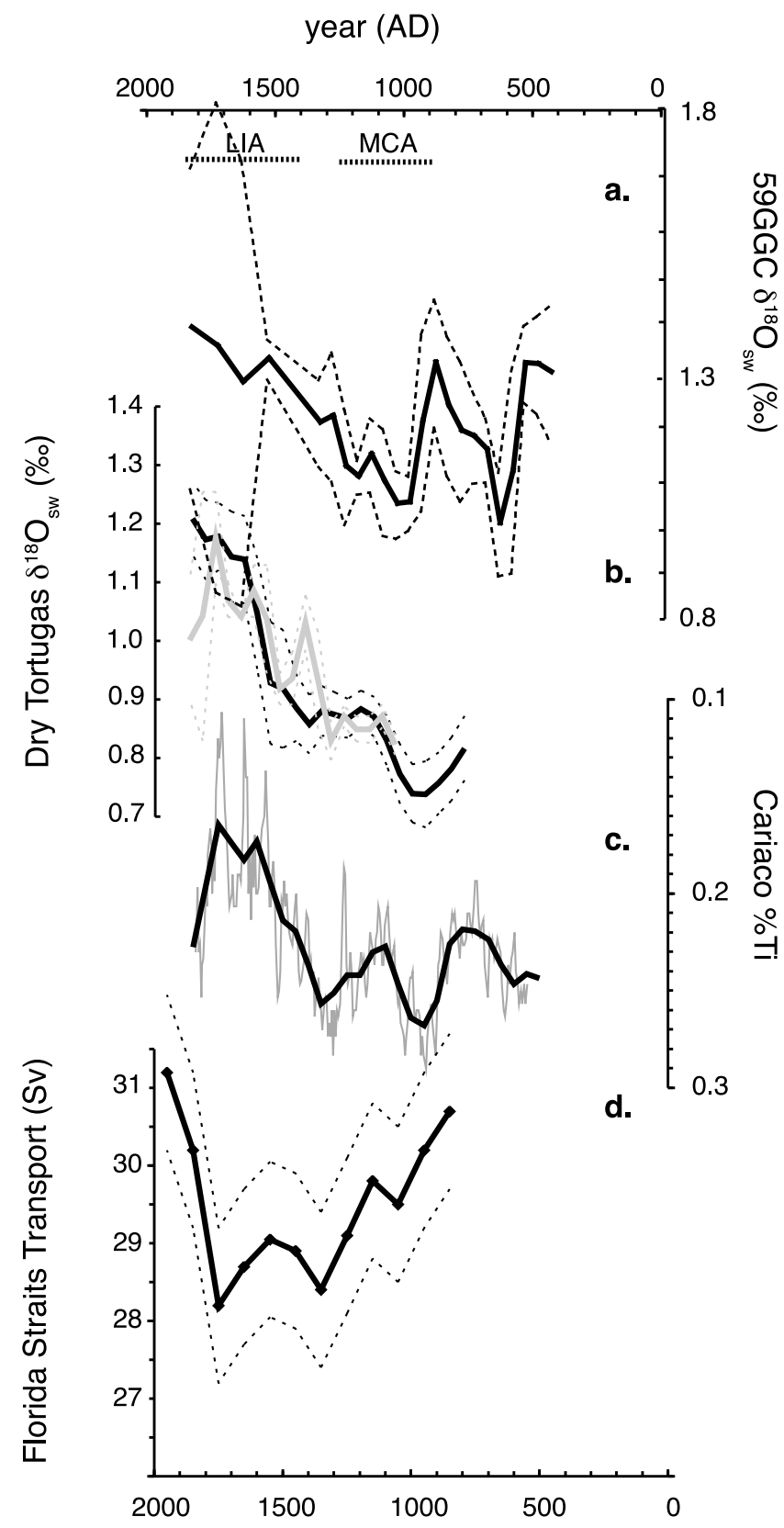

Figure 9. (a) Binned $59 \mathrm{GGC} \delta^{18} \mathrm{O}_{\mathrm{sw}}$ and one sigma standard error. (b) Binned Dry Tortugas $\delta^{18} \mathrm{O}_{\text {sw }}$ and one sigma standard error for cores 79GGC (black) and 62MC (gray) [Lund and Curry, 2006]. (c) Cariaco Basin percent titanium [Haug et al., 2001]. (d) Florida Straits transport [Lund et al., 2006]. The approximate timings of the MCA and LIA are marked.

Northern Hemisphere and in other portions of the lowlatitude western North Atlantic.

[27] Carolina Slope SST cooled as NAO-like circulation became less positive after $\sim 1250$ A.D., eventually reaching its coldest values near 1500 A.D. when the NAO was entering its negative phase. Although 59GGC does not robustly resolve the timing or the trend of SST variability since the LIA, the rise in mean SST near the core top hints that our data may be consistent with increased solar irradi- ance, a more positive NAO-like circulation, and anthropogenic warming in recent centuries.

[28] Solar irradiance-induced changes in NAO-like circulation provide a plausible explanation for our reconstructed SST variability, but similarities between the AMO and Carolina Slope SST since the 1850s (Figures 2a and 2b) suggest AMOC variability may also be important. Changes in the AMOC are characterized by SST anomalies of a single sign throughout the North Atlantic [Knight et al., 2005; Stouffer et al., 2006]. Although the amplitude of these anomalies is damped along the Carolina Slope, a weaker AMOC is characterized by cooler Atlantic SSTs North of the equator while the opposite holds for a stronger AMOC.

[29] Despite considerable uncertainty in reconstructions of the AMOC during the past two millennia, many records suggest overturning was stronger during the MCA and weaker during the LIA. Carbon isotopes from a Bermuda Rise sediment core suggest northern-sourced deepwater was enhanced from $\sim 0-1000$ A.D., but was significantly reduced during the LIA [Keigwin and Boyle, 2000]. Similarly, evidence suggesting that vigorous flow of Iceland-Scotland Overflow Water near 1000 A.D. became weaker during the LIA [Bianchi and McCave, 1999] is broadly consistent with a $\sim 10 \%$ reduction in northward transport through the Florida Straits between 1000 A.D. and 1500 A.D. [Lund et al., 2006]. Although not conclusive, these proxy records clearly demonstrate the possibility that changes in the AMOC could have contributed to climate variability during the past 2000 years [Denton and Broecker, 2008].

[30] Estimates of subpolar SST from planktic foraminifera show a pronounced warming around 1250 A.D. [Andersson et al., 2003] that is nearly synchronous with our Carolina Slope record and consistent with the pattern expected from an enhanced AMOC (Figure 8b). North Atlantic drift ice records (Figure 8c) also suggest AMOC variability, possibly forced by solar irradiance, was a prominent control on late Holocene Atlantic climate [Bond et al., 2001]. However, other high-latitude North Atlantic proxy records show little evidence for warming near 1250 A.D. [Cronin et al., 2010]. Assuming such differences cannot be attributed to age model uncertainties, they do not support a synchronous, basinwide SST anomaly forced by AMOC variability. Rather, we suggest that any influence of the AMOC on Carolina Slope SST variability during the past two millennia was likely part of complex ocean-atmosphere coupling. For example, coupled model simulations indicate sustained positive NAO-like circulation patterns can enhance the AMOC [Delworth and Dixon, 2000], and can cause an in-phase warming between the subtropical and subpolar Atlantic on multidecadal timescales [Visbeck et al., 1998] that is also generally consistent with Figure 8 .

\section{2. $\delta^{18} \mathrm{O}_{\text {sw }}$ Variability}

[31] Carolina Slope $\delta^{18} \mathrm{O}_{\mathrm{sw}}$ suggests variable but generally fresh MCA conditions that became more saline during the LIA (Figure 9a). This pattern differs from Gulf of Mexico [Richey et al., 2007] and Great Bahama Bank $\delta^{18} \mathrm{O}_{\mathrm{sw}}$ reconstructions, but is similar to a record from the Dry Tortugas [Lund and Curry, 2006] (Figure 9b). Because models suggest the amount and the $\delta^{18} \mathrm{O}$ of precipitation near our site remained relatively unchanged during the late Holocene [LeGrande and Schmidt, 2009], we suggest 

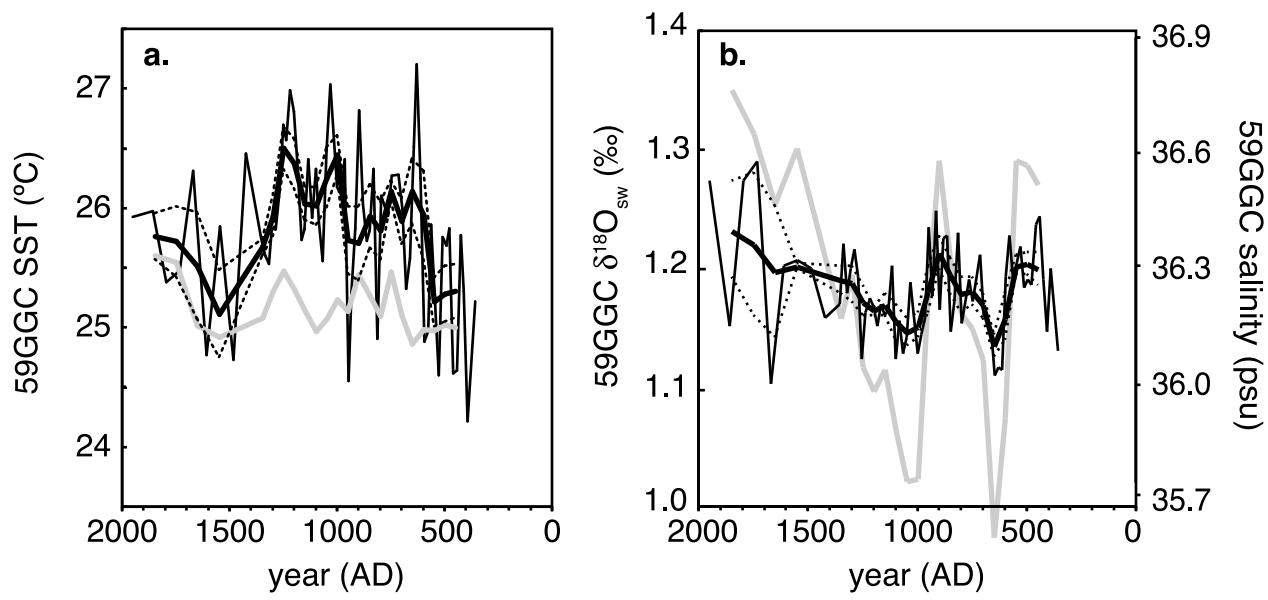

Figure 10. (a) Average 59GGC SST based on the calibration of Arbuszewski et al. [2010] at each depth after applying our age model (thin line) and in overlapping bins (thick line) with associated one sigma standard error (dashed line). The binned mean from Figure 6 is shown for comparison (gray line). (b) As in Figure $10 \mathrm{a}$ for $59 \mathrm{GGC} \delta^{18} \mathrm{O}_{\mathrm{sw}}$ converted from salinity using equation (3).

changes in Carolina Slope $\delta^{18} \mathrm{O}_{\mathrm{sw}}$ reflect the tropical Atlantic evaporation/precipitation balance. Cariaco Basin percent titanium [Haug et al., 2001], a proxy for Atlantic Intertropical Convergence Zone (ITCZ) precipitation, suggests a Northerly ITCZ freshened the tropical Atlantic during the MCA leading to a negative salinity anomaly. Advection of this lowsalinity anomaly in surface currents may then explain relatively low Carolina Slope $\delta^{18} \mathrm{O}_{\text {sw }}$ during the MCA.

[32] Cooling throughout much of the low-latitude North Atlantic during the LIA [Keigwin, 1996; Lund and Curry, 2006; Richey et al., 2007; Saenger et al., 2009a] likely forced the ITCZ southward [Chiang et al., 2002; Saenger et al., 2009b] resulting in a positive tropical Atlantic salinity anomaly. The northward transport of this anomaly in surface currents may then have caused the trend toward higher $\delta^{18} \mathrm{O}_{\mathrm{sw}}$ during the LIA. Consistent with the interpretation of Lund and Curry [2006], this advective mechanism also explains synchronous variability in $\delta^{18} \mathrm{O}_{\mathrm{sw}}$ near the Dry Tortugas, which lies along the Florida Current-Gulf Stream transport path.

[33] If changes in Carolina Slope $\delta^{18} \mathrm{O}_{\mathrm{sw}}$ are caused by advected anomalies, the volume of water transported to the site may also be important. Evidence that Florida Current transport was reduced by $\sim 10 \%$ during the LIA [Lund et al., 2006] (Figure 9d), hints that reduced transport may have contributed to more positive Carolina Slope $\delta^{18} \mathrm{O}_{\mathrm{sw}}$ anomalies at that time. However, the Carolina Slope remained relatively fresh throughout the decline in transport from 800 to 1400 A.D., suggesting that volume of transport is of secondary importance to $\delta^{18} \mathrm{O}_{\mathrm{sw}}$ variability.

\subsection{Salinity Effects on $\mathrm{Mg} / \mathrm{Ca}$}

[34] Recent evidence suggests that the high salinity at our subtropical site could influence G. ruber $\mathrm{Mg} / \mathrm{Ca}$ [Ferguson et al., 2008; Mathien-Blard and Bassinot, 2009; Arbuszewski et al., 2010]. To assess the importance of this effect, we applied a recent calibration that simultaneously solves for mean annual SST and salinity using $\mathrm{Mg} / \mathrm{Ca}, \delta^{18} \mathrm{O}_{\mathrm{c}}$ and $\Delta \mathrm{CO}_{3}^{2-}$, where $\Delta \mathrm{CO}_{3}^{2-}$ is the difference between the carbonate ion concentration and saturation at a given depth in $\mu \mathrm{mol} \mathrm{kg}$
[Arbuszewski et al., 2010]. We estimated 59GGC $\Delta \mathrm{CO}_{3}^{2-}$ to be $24.62 \mu \mathrm{mol} \mathrm{kg}^{-1}$ based on the $1250 \mathrm{~m}$ horizon of Anderson and Archer's [2002] Atlantic carbonate ion concentration profile. This value was considered to be constant. Because the calibration of Arbuszewski et al. [2010] solves for SST and salinity, the later was converted to $\delta^{18} \mathrm{O}_{\mathrm{sw}}$ using equation (3) to more easily compare the two methods.

[35] Alternate SST, salinity and $\delta^{18} \mathrm{O}_{\text {sw }}$ estimates average $25.82 \pm 0.66^{\circ} \mathrm{C}, 36.28 \pm 0.11 \mathrm{psu}$ and $1.19 \pm 0.04 \%$, respectively. The comparable values using equations (1)-(3) are $25.14 \pm 0.40^{\circ} \mathrm{C}, 36.21 \pm 0.55 \mathrm{psu}$ and $1.17 \pm 0.18 \%$, respectively (Figure 10). The trends of the alternate SST and $\delta^{18} \mathrm{O}_{\mathrm{sw}}$ estimates are generally similar to those based on traditional methods, and they do not fundamentally change our conclusions. Although SSTs calculated from Arbuszewski et al. [2010] suggest the MCA was significantly warmer than 59GGC's core top, the onset of LIA cooling still lags with respect to other hemispheric and regional temperature records. Similarly, alternate $\delta^{18} \mathrm{O}_{\mathrm{sw}}$ estimates exhibit the same pattern of variability, and still support a possible link with the tropical ITCZ.

[36] A notable difference between the methods is the amplitude of SST and $\delta^{18} \mathrm{O}_{\mathrm{sw}}$ variability. Using Arbuszewski et al. [2010] increases the standard deviation $(1 \sigma)$ of mean SST by $0.16^{\circ} \mathrm{C}$ and decreases that of $\delta^{18} \mathrm{O}_{\text {sw }}$ variability by $0.14 \%$. Given that SST has varied by more than $1^{\circ} \mathrm{C}$ in recent decades (Figure 2), both methods estimate a reasonable range of SST values. In contrast, the amplitude of $\delta^{18} \mathrm{O}_{\mathrm{sw}}$ variability reconstructed using equations (1) and (2) (Figure 6) may be unrealistically large given that the estimated Carolina Slope salinity variability of $\sim 0.2 \mathrm{psu}$ (Figure 2 ) is equivalent to only $\sim 0.06 \%$ o based on equation (3). Although we cannot rule out large salinity variations in the past, the damped salinity and $\delta^{18} \mathrm{O}_{\text {sw }}$ estimates calculated from Arbuszewski et al. [2010] seem more realistic when compared to modern variability.

\section{Conclusions}

[37] Carolina Slope SST and $\delta^{18} \mathrm{O}_{\mathrm{sw}}$ show small variations over the last two millennia that exhibit distinct differences 
from regional and Northern Hemisphere trends. SST trends are likely to be modulated by variations in atmospheric and oceanic circulation associated with NAO-like circulation patterns. Consistent with modern observations [Marshall et al., 2001], more positive NAO-like conditions during the MCA may have shifted the Atlantic's zero wind stress curl line northward, reduced ocean-atmosphere heat flux and prolonged warmth. Enhanced AMOC may have also contributed to this warm anomaly. Only after NAO-like circulation shifted toward a more negative configuration after $\sim 1250$ A.D. did the Carolina Slope cool into the LIA.

[38] Variations in $\delta^{18} \mathrm{O}_{\text {sw }}$ appear to be tightly linked with tropical Atlantic hydrology through surface ocean circulation. Shifts in the mean latitude of the ITCZ may have caused fresh tropical Atlantic anomalies during the MCA and more saline conditions during the LIA. Northward transport of these anomalies to the Carolina Slope by the Florida CurrentGulf Stream system provides a probable mechanism for synchronous variability between the two regions.

[39] Acknowledgments. We are grateful for the sampling and analytical assistance of Y. Rosenthal, P. Field, W. Curry, D. Ostermann, S. Praetorious, K. Rose, S. Birdwhistell, and L. Zou. T. Joyce, M. McCartney, Y. Kwon, B. Peña-Molino, T. Cronin, F. Gibbons, C. Ponton, and three anonymous reviewers provided thoughtful discussions and comments. This study was supported by the Woods Hole Oceanographic Institution's Ocean and Climate Change Institute $(\mathrm{OCCI})$ and by the National Science Foundation.

\section{References}

Anand, P., H. Elderfield, and M. H. Conte (2003), Calibration of Mg/Ca thermometry in planktonic foraminifera from a sediment trap time series, Paleoceanography, 18(2), 1050, doi:10.1029/2002PA000846.

Anderson, D. M., and D. Archer (2002), Glacial-interglacial stability of ocean $\mathrm{pH}$ inferred from foraminifer dissolution rates, Nature, 416, 70-73, doi:10.1038/416070a.

Andersson, C., B. Risebrokakken, E. Jansen, and S. O. Dahl (2003), Late Holocene surface ocean conditions of the Norwegian Sea (Vøring Plateau), Paleoceanography, 18(2), 1044, doi:10.1029/2001PA000654.

Arbuszewski, J., P. deMenocal, A. Kaplan, and E. C. Farmer (2010), On the fidelity of shell-derived $\delta^{18} \mathrm{O}_{\text {seawater }}$ estimates, Earth Planet. Sci. Lett., 300, 185-196, doi:10.1016/j.epsl.2010.10.035.

Bard, E., and M. Frank (2006), Climate change and solar variability: What's new under the sun?, Earth Planet. Sci. Lett., 248, 1-14, doi:10.1016/j. epsl.2006.06.016.

Bard, E., G. Raisbeck, F. Yiou, and J. Jouzel (2000), Solar irradiance during the last 1200 years based on cosmogenic nuclides, Tellus, Ser. B, 52, 985-992, doi:10.1034/j.1600-0889.2000.d01-7.x.

Battisti, D. S., U. Bhatt, and M. A. Alexander (1995), A modeling study of interannual variability in the wintertime North Atlantic Ocean, J. Clim. 8, 3067-3083, doi:10.1175/1520-0442(1995)008<3067:AMSOTI $>2.0$. $\mathrm{CO} ; 2$.

Bianchi, G. G., and I. N. McCave (1999), Holocene periodicity in North Atlantic climate and deep-ocean flow south of Iceland, Nature, 397, 515-517, doi:10.1038/17362.

Bond, G., B. Kromer, J. Beer, R. Muscheler, M. N. Evans, W. Showers, S. Hoffmann, R. Lotti-Bond, I. Hajdas, and G. Bonani (2001), Persistent solar influence on North Atlantic climate during the Holocene, Science, 294, 2130-2136, doi:10.1126/science.1065680.

Boyle, E. A., and L. D. Keigwin (1985), Comparison of Atlantic and Pacific paleochemical records for the last 215,000 years: Changes in deep ocean circulation and chemical inventories, Earth Planet. Sci. Lett., 76, 135-150, doi:10.1016/0012-821X(85)90154-2.

Butzin, M., M. Prange, and G. Lohmann (2005), Radiocarbon simulations for the glacial ocean: The effects of wind stress, Southern Ocean sea ice and Heinrich events, Earth Planet. Sci. Lett., 235, 45-61, doi:10.1016/j. eps1.2005.03.003

Carton, J. A., and B. S. Giese (2008), A reanalysis of ocean climate using Simple Ocean Data Assimilation (SODA), Mon. Weather Rev., 136 , 2999-3017, doi:10.1175/2007MWR1978.1.

Cayan, D. R. (1992), Latent and sensible heat flux anomalies over the Northern oceans: The connection to monthly atmospheric circulation,
J. Clim., 5, 354-369, doi:10.1175/1520-0442(1992)005<0354:LASHFA> 2.0.CO;2.

Chiang, J. C. H., Y. Kushnir, and A. Giannini (2002), Deconstructing Atlantic Intertropical Convergence Zone variability: Influence of the local cross-equatorial sea surface temperature gradient and remote forcing from the eastern equatorial Pacific, J. Geophys. Res., 107(D1), 4004, doi:10.1029/2000JD000307.

Cronin, T. M., K. Hayo, R. C. Thunell, G. S. Dwyer, C. Saenger, and D. A. Willard (2010), The Medieval Climate Anomaly and Little Ice Age in Chesapeake Bay and the North Atlantic Ocean, Palaeogeogr. Palaeoclimatol. Palaeoecol., 297, 299-310, doi:10.1016/j.palaeo.2010.08.009.

Delworth, T. L., and K. W. Dixon (2000), Implications of the recent trend in the Arctic/North Atlantic Oscillation for the North Atlantic thermohaline circulation, J. Clim., 13, 3721-3727, doi:10.1175/1520-0442(2000) 013<3721:IOTRTI $>2.0 . \mathrm{CO} ; 2$

Denton, G. H., and W. S. Broecker (2008), Wobbly ocean conveyor circulation during the Holocene?, Quat. Sci. Rev., 27, 1939-1950, doi:10.1016/j. quascirev.2008.08.008.

Deuser, W. G., and E. H. Ross (1989), Seasonally abundant planktonic foraminifera of the Sargasso Sea: Succession, deep-water fluxes, isotopic compositions, and paleoceanographic implication, J. Foraminiferal Res. 19, 268-293, doi:10.2113/gsjfr.19.4.268

Enfield, D. B., A. M. Mestas-Nunez, and P. J. Trimble (2001), The Atlantic multidecadal oscillation and its relation to rainfall and river flows in the continental U.S, Geophys. Res. Lett., 28, 2077-2080, doi:10.1029/ 2000GL012745.

Fairbanks, R. G., R. A. Mortlock, T. Chiu, L. Cao, A. Kaplan, T. P. Guilderson, T. W. Faribanks, A. L. Bloom, P. M. Grootes, and M. Nadeau (2005), Radiocarbon calibration curve spanning 0 to 50,000 years BP based on paired ${ }^{230} \mathrm{Th} /{ }^{234} \mathrm{U} /{ }^{238} \mathrm{U}$ and ${ }^{14} \mathrm{C}$ dates on pristine corals, Quat. Sci. Rev., 24, 1781-1796, doi:10.1016/j.quascirev.2005.04.007.

Ferguson, J. E., G. M. Henderson, M. Kucera, and R. E. M. Rickaby (2008), Systematic change of foraminiferal $\mathrm{Mg} / \mathrm{Ca}$ ratios across a strong salinity gradient, Earth Planet. Sci. Lett., 265, 153-166, doi:10.1016/j. eps1.2007.10.011.

Goosse, H., H. Renssen, A. Timmermann, and R. S. Bradley (2005), Internal and forced climate variability during the last millennium: A model-data comparison using ensemble simulations, Quat. Sci. Rev., 24, 1345-1360, doi:10.1016/j.quascirev.2004.12.009

Halliwell, G. R. (1998), Simulation of North Atlantic decadal/multidecadal winter SST anomalies driven by basin-scale atmospheric circulation anomalies, J. Phys. Oceanogr., 28, 5-21, doi:10.1175/1520-0485(1998) 028<0005:SONADM $>2.0 . \mathrm{CO} ; 2$.

Haug, G. H., K. A. Hughen, D. M. Sigman, L. C. Peterson, and U. Rohl (2001), Southward migration of the intertropical convergence zone through the Holocene, Science, 293, 1304-1308, doi:10.1126/science. 1059725.

Hegerl, G. C., T. J. Crowley, M. Allen, W. T. Hyde, H. N. Pollack, J. Smerdon, and E. Zorita (2007), Detection of human influence on a new, validated 1500-year temperature reconstruction, J. Clim., 20, 650-666, doi:10.1175/ JCLI4011.1.

Hurrell, J. W., Y. Kushnir, G. Ottersen, and M. Visbeck (2003), An Overview of the North Atlantic Oscillation, in The North Atlantic Oscillation: Climatic Significance and Environmental Impact, Geophys. Monogr. Ser., vol. 134, pp. 1-35, AGU, Washington, D. C.

Keigwin, L. D. (1996), The Little Ice Age and Medieval warm period in the Sargasso Sea, Science, 274, 1504-1508, doi:10.1126/science.274.5292.1504.

Keigwin, L. D., and E. A. Boyle (2000), Detecting Holocene changes in thermohaline circulation, Proc. Natl. Acad. Sci. U. S. A., 97, 1343-1346, doi:10.1073/pnas.97.4.1343.

Knight, J. R., R. J. Allan, C. K. Folland, M. Vellinga, and M. E. Mann (2005), A signature of persistent natural thermohaline circulation cycles in observed climate, Geophys. Res. Lett., 32, L20708, doi:10.1029/ 2005GL024233.

Laird, K. R., S. C. Fritz, K. A. Maasch, and B. F. Cumming (1996), Greater drought intensity and frequency before AD 1200 in the Northern Great Plains, USA, Science, 384, 552-554.

Lean, J. L., and D. H. Rind (2008), How natural and anthropogenic influence alter global and regional surface temperatures: 1889 to 2006, Geophys. Res. Lett., 35, L18701, doi:10.1029/2008GL034864.

Lean, J., J. Beer, and R. Bradley (1995), Reconstruction of solar irradiance since 1610: Implications for climate change, Geophys. Res. Lett., 22, 3195-3198, doi:10.1029/95GL03093.

LeGrande, A. N., and G. A. Schmidt (2006), Global gridded data set of the oxygen isotopic composition in seawater, Geophys. Res. Lett., 33, L12604, doi:10.1029/2006GL026011.

LeGrande, A. N., and G. A. Schmidt (2009), Sources of Holocene variability of oxygen isotopes in paleoclimate archives, Clim. Past, 5, 441-455, doi:10.5194/cp-5-441-2009. 
Lund, D. C., and W. Curry (2006), Florida Current surface temperature and salinity variability during the last millennium, Paleoceanography, 21, PA2009, doi:10.1029/2005PA001218.

Lund, D. C., J. Lynch-Stieglitz, and W. B. Curry (2006), Gulf Stream density structure and transport during the past millennium, Nature, 444, 601-604, doi:10.1038/nature05277.

Macdonald, A. M., and C. Wunsch (1996), An estimate of global ocean circulation and heat fluxes, Nature, 382, 436-439, doi:10.1038/382436a0.

Mann, M. E., Z. H. Zhang, M. K. Hughes, R. S. Bradley, S. K. Miller, S. Rutherford, and F. B. Ni (2008), Proxy-based reconstructions of hemispheric and global surface temperature variations over the past two millennia, Proc. Natl. Acad. Sci. U. S. A., 105, 13,252-13,257, doi:10.1073/ pnas.0805721105.

Mann, M. E., Z. H. Zhang, S. Rutherford, R. S. Bradley, M. K. Hughes, D. Shindell, C. Ammann, G. Faluvegi, and F. B. Ni (2009), Global signatures and dynamical origins of the Little Ice Age and Medieval Climate Anomaly, Science, 326, 1256-1260, doi:10.1126/science.1177303.

Marshall, J., H. Johnson, and J. Goodman (2001), Study of the interaction of the North Atlantic Oscillation with ocean circulation, J. Clim., 14, 1399-1421, doi:10.1175/1520-0442(2001)014<1399:ASOTIO>2.0. $\mathrm{CO} ; 2$.

Mathien-Blard, E., and F. Bassinot (2009), Salinity bias on the foraminifera $\mathrm{Mg} / \mathrm{Ca}$ thermometry: Correction procedure and implications for past ocean hydrographic reconstructions, Geochem. Geophys. Geosyst., 10 Q12011, doi:10.1029/2008GC002353.

Mignot, J., and C. Frankignoul (2003), On the interannual variability of surface salinity in the Atlantic, Clim. Dyn., 20, 555-565.

Mulitza, S., D. Boltovskoy, B. Donner, H. Meggers, A. Paul, and G. Wefer (2003), Temperature: $\delta^{18} \mathrm{O}$ relationships of planktonic foraminifera collected from surface waters, Palaeogeogr. Palaeoclimatol. Palaeoecol. 202, 143-152, doi:10.1016/S0031-0182(03)00633-3.

Richey, J. N., R. Z. Poore, B. P. Flower, and T. Quinn (2007), $1400 \mathrm{yr}$ multiproxy record of climate variability from the Northern Gulf of Mexico, Geology, 35, 423-426, doi:10.1130/G23507A.1.

Rohling, E. J. (2007), Progress in paleosalinity: Overview and presentation of a new approach, Paleoceanography, 22, PA3215, doi:10.1029/ 2007PA001437.

Rosenthal, Y., P. Lam, E. A. Boyle, and J. Thomson (1995), Authigenic cadmium enrichments in suboxic sediments: Precipitation and postdepositional mobility, Earth Planet. Sci. Lett., 132, 99-111, doi:10.1016/0012$821 \mathrm{X}(95) 00056-\mathrm{I}$

Sachs, J. (2007), Cooling of Northwest Atlantic slope waters during the Holocene, Geophys Res Lett., 34, L03609, doi:10.1029/2006GL028495.

Saenger, C., A. L. Cohen, D. W. Oppo, R. B. Halley, and J. E. Carill (2009a), Surface temperature trends and variability in the low-latitude
North Atlantic since 1552, Nat. Geosci., 2, 492-495, doi:10.1038/ ngeo552.

Saenger, C., P. Chang, L. Ji, D. W. Oppo, and A. L. Cohen (2009b), Tropical Atlantic climate response to low-latitude and extratropical sea-surface temperature: A Little Ice Age perspective, Geophys. Res. Lett., 36 , L11703, doi:10.1029/2009GL038677.

Schmidt, G. A. (1999), Error analysis of paleosalinity calculations, Paleoceanography, 14, 422-429, doi:10.1029/1999PA900008.

Schmitz, W. J., and M. S. McCartney (1993), On the North Atlantic Circulation, Rev. Geophys., 31, 29-49, doi:10.1029/92RG02583.

Schmitz, W. J., and P. L. Richardson (1991), On the sources of the Florida Current, Deep Sea Res., Part A, 38, S379-S409.

Shindell, D. T., G. A. Schmidt, M. E. Mann, D. Rind, and A. Waple (2001) Solar forcing of regional climate change during the Maunder Minimum, Science, 294, 2149-2152, doi:10.1126/science.1064363.

Smith, T. M., R. W. Reynolds, T. C. Peterson, and J. Lawrimore (2008), Improvements to NOAA's historical merged land-ocean surface temperature analysis (1880-2006), J Clim , 21, doi:10.1175/2007JCLI2100.1.

Stouffer, R. J., et al. (2006), Investigating the causes of the response of the thermohaline circulation to past and future climate changes, J. Clim., 19, 1365-1387, doi:10.1175/JCLI3689.1.

Trouet, V., J. Esper, N. E. Graham, A. Baker, J. D. Scourse, and D. C. Frank (2009), Persistent positive North Atlantic Oscillation mode dominated the Medieval Climate Anomaly, Science, 324, 78-80, doi:10.1126/ science. 1166349

Usoskin, I. G., M. Korte, and G. A. Kovaltsov (2008), Role of centennial geomagnetic changes in local atmospheric ionization, Geophys. Res. Lett., 35, L05811, doi:10.1029/2007GL033040.

Visbeck, M., H. Cullen, G. Krahmann, and N. Naik (1998), An ocean model's response to North Atlantic Oscillation-like wind forcing, Geophys. Res. Lett., 25, 4521-4524, doi:10.1029/1998GL900162.

Wang, L. P., and C. J. Koblinsky (1996), Annual variability of the subtropical recirculations in the North Atlantic and North Pacific: A Topex/ Poseidon study, J. Phys. Oceanogr., 26, 2462-2479, doi:10.1175/15200485(1996)026<2462:AVOTSR >2.0.CO;2.

R. E. Came, Department of Earth Sciences, University of New Hampshire, James Hall, Rm. 314, Durham, NH 03824, USA.

A. L. Cohen, L. D. Keigwin, and D. W. Oppo, Woods Hole Oceanographic Institution, McLean Laboratory, 266 Woods Hole Rd., MS 23, Woods Hole, MA 02543, USA.

C. Saenger, Department of Geology and Geophysics, Yale University, Kline Geological Laboratory, 210 Whitney Ave., New Haven, CT 06511 , USA. (casey.saenger@yale.edu) 